\title{
Pengaruh Pengetahuan, Pengalaman, Skeptisme Profesional, dan Intuisi APIP Dalam Mendeteksi Kecurangan Pada Inspektorat Provinsi NTB
}

\author{
Muhammad Idham ${ }^{1}$ \\ Fakultas Ekonomi dan Bisnis \\ Universitas Mataram, Indonesia
}

\author{
Lalu M. Furkan² \\ Fakultas Ekonomi dan Bisnis \\ Universitas Mataram, Indonesia
}

\section{Endar Pituringsih ${ }^{3}$ \\ Fakultas Ekonomi dan Bisnis Universitas Mataram, Indonesia}

Surel: hambinhoed@gmail.com

\section{ABSTRAK}

Penelitian ini bertujuan untuk menganalisis Pengaruh Pengetahuan, Pengalaman, Skeptisme Profesional, Dan Intuisi Aparat Pengawas Intern Pemerintah Dalam Mendeteksi Kecurangan (Fraud) Pada Inspektorat Provinsi NTB. Responden dari penelitian ini sebanyak 49 orang yang mempunyai jabatan fungsional. Teknik pengumpulan data dilakukan dengan kuesioner dan pengambilan data dengan metode sensus. Teknik analisis data menggunakan analisis regresi berganda. Hasil penelitian menunjukkan bahwa pengalaman dan skeptisme professional berpengaruh positif signifikan terhadap Pendeteksian Kecurangan. Sedangkan pengetahuan dan intuisi berpengaruhnegatif terhadap Pendeteksian Kecurangan. Implikasi teoritis dari penelitian ini adalah dapat memperkuat hasil-hasil penelitian terdahulu bahwa pengetahuan, pengalaman, skeptisme profesionalisme dan intuisi memberikan pengaruh terhadap pendeteksian kecurangan. Implikasi praktis penelitian ini berguna sebagai sarana untuk memberikan informasi atau referensi bagi auditor, khususnya yang memiliki jabatan fungsional auditor. Sedangkan implikasi kebijakan penelitian dapat dijadikan tolak ukur dan evaluasi terkait pendeteksian kecuragan dalam meningkatkankualitas dan kinerja auditor sebagai pengawas intern pemerintah.

Kata Kunci: Pengetahuan; Pengalaman; Skeptisme Profesionalisme; Intuisi; Pendeteksian Kecurangan.

\section{The Influence of Knowledge, Experience, Professional Skepticism, and APIP Intuition in Detecting Fraud in NTB Provincial Inspectorate}$$
\text { ABSTRACT }
$$

This study aims to analyze the effect of knowledge, experience, professional skepticism, and intuition of government internal supervisors in detecting fraud at the NTB Provincial Inspectorate. Respondents from this study as many as 49 people whohave functional positions. The technique of collecting data is by using a questionnaire and collecting data by using the census method. The data analysis technique used multiple regression analysis. The results showed that professional experience and skepticism had a significant positive effect on Fraud Detection. Meanwhile, knowledge and intuition have a negative effect on Fraud Detection. The theoretical implication of this research is to strengthen the results of previous studies that knowledge, experience, professional skepticism and intuition have an influence on fraud detection. The practical implications of this research are useful as a means to provide information or references for auditors, especially those who have an auditor's functional position. Meanwhile, the implications of research policies can be used as benchmarks and evaluations related to fraud detection in improving the quality and performance of auditors as government internal supervisors.
\end{abstract}

Keywords: Knowledge; Experience; Profesionalisme Skepticism; Intuition; Fraud Detection.

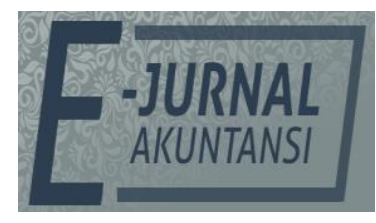

e-ISSN 2302-8556

Vol. 31 No. 12

Denpasar, Desember 2021 Hal. 3244-3258

DOI:

10.24843/EJA.2021.v31.i12.p

PENGUTIPAN:

Idham, M., Furkan, L. M. \& Pituringsih, E. (2021). Pengaruh Pengetahuan, Pengalaman, Skeptisme Profesional, Dan Intuisi APIP Dalam Mendeteksi

Kecurangan Pada Inspektorat Provinsi NTB. E-Jurnal Akuntansi, 31(12), 3244-3258

RIWAYAT ARTIKEL: Artikel Masuk: 13 Agustus 2021 Artikel Diterima: 31 Desember 2019

Artikel dapat diakses: https:/ / ojs.unud.ac.id/index.php/Akuntansi/index 


\section{PENDAHULUAN}

Permenpan Nomor 5 Tahun 2008 menjelaskan bahwa pengawasan intern pemerintah merupakan fungsi manajemen yang penting dalam menyelenggarakan pemerintahan, dimana fungsi pengawasan intern adalah untuk mengetahui apakah suatu instansi pemerintah telah melaksanakan kegiatan sesuai dengan tugas dan fungsinya secara efektif dan efisien, serta sesuai dengan rencana, kebijakan yang telah ditetapkan. Untuk mendorong terwujudnya good governance dan clean government serta mendukung penyelenggaraan pemerintahan yang efektif, efisien, transparan, akuntabel serta bersih dan bebas dari praktik korupsi, kolusi, dan nepotisme (Menteri Negara Pendayagunaan Aparatur Negara Republik Indonesia, 2008), maka diperlukan adanya pengawasan intern atas penyelenggaraan pemerintahan.

Tiga aspek utama menurut (Mardiasmo, 2005), yang mendukung terlaksananya pemerintahan yang baik (good governance), yaitu pengawasan, pengendalian, dan pemeriksaan. Pengawasan yang dimaksud adalah kegiatan yang dijalankan oleh pihak di luar eksekutif, yakni masyarakat dan Dewan Perwakilan Rakyat Daerah (DPRD) dalam mengawasi kinerja pemerintahan. Pengendalian (control) merupakan metode yang dijalankan oleh eksekutif untuk menjamin bahwa sistem dan kebijakan manajemen dilakukan dengan baik sehingga tujuan organisasi dapat terlaksana dengan baik. Sedangkan pemeriksaan (audit) adalah aktifitas yang dilakukan oleh pihak yang mempunyai independensi dan kompetensi professional untuk memeriksa apakah hasil kinerja pemerintah telah sesuai dengan standar yang telah ditetapkan. Ketiga aspek tersebut harus dijalankan dengan sinergi agar pemerintahan yang baik dapat terwujud. Adanya konflik kepentingan dan asimetri informasi yang dilakukan oleh prinsipal dan agen memberikan kesempatan terhadap agen untuk bertindak oportunis, yakni untuk mendapatkan keuntungan pribadi. Kondisi ini akan menimbulkan biaya keagenan (agency cost) yang terdiri dari: pengeluaran pemantauan berdasarkan prinsip, pengeluaran ikatan oleh agen, dan kerugian residual (Jensen, M. C., \& Meckling, 1976) Kegiatan pengawasan yang dilakukan oleh principle pada sektor publik, khususnya di daerah tidak terlepas dari peran serta aparat pengawas intern pemerintah (APIP) dalam menjaga keberlangsungan kegiatan operasional pemerintahan agar sesuai dengan koridor hukum yang berlaku.

Selama kurun waktu 2018, Omdusman RI perwakilan Nusa Tenggara Barat mencatat pengaduan masyarakat pada hal pelayanan publik. Berdasarkan kelompok instansi terlapor, pemerintah daerah menempati urutan tertinggi sebesar 75 laporan. Kasus terbaru dilakukannya audit investigasi oleh Badan Pemeriksa keuangan pada sektor wisata NTB, karena BPK melihat pariwisata menjadi salah satu sektor unggulan pemprov NTB sesuai yang tertuang dalam visi misi NTB Gemilang. Alasan proses audit dilakukan karena pariwisata yang menjadi andalan pemprov tidak berkontribusi maksimal untuk menggenjot pendapatan daerah. Tujuan audit investigasi untuk melihat rasio arus wisata dengan pemasukan keuangan daerah (Bali.bisnis.com, 2021). Segmen yang diusut oleh BPK adalah pemasukan riil berdasarkan identifikasi potensi pendapatan daerah dari sektor pariwisata. Hal ini dilakukan karena ditemukan kejanggalan potensi pemasukan daerah yang seharusnya 1 milyar namun hanya masuk ke kas 
daerah 100 juta sehigga BPK mengangap hal ini merupakan sebuah kejanggalan (SuaraNTB.com, 2019).

Inspektorat Daerah adalah Aparat Pengawas Instern Pemerintah (APIP) yang salah satu tugasnya melakukan pemeriksaan terhadap pemerintah daerah. Menurut (Falah, 2006) Inspektorat Daerah mempunyai tugas menyelenggarakan kegiatan pengawasan umum pemerintah daerah dan tugas lain yang diberikan Kepala Daerah, sehingga dalam tugasnya Inspektorat sama dengan auditor internal. Audit internal adalah audit yang dilakukan oleh unit pemeriksa yang merupakan bagian dari organisasi yang diawasi (Mardiasmo, 2005). Pembinaan kepada instansi pemerintah daerah dalam melaksanakan tugasnya dan bisa menjamin pelaksanaannya sesuai dengan peraturan yang berlaku merupakan salah satu tugas A parat Pengawas Intern Pemerintah. APIP juga harus berusaha meningkatkan seluruh sumber daya untuk tercapainya quality assurance terhadap pelaksanaan tugas OPD sehingga tercapai penyelenggaraan pemerintahan daerah yang memenuhi prinsip-prinsip good governance (Loho, 2014).

Tugas Inspektorat Provinsi Nusa Tenggara Barat sebagaimana tertuang dalam Peraturan Daerah Nomor 8 tahun 2008 adalah untuk melaksanakan pengawasan terhadap pelaksanaan urusan pemerintahan di daerah Provinsi, pelaksanaan pembinaan atas penyelenggaraan pemerintahan daerah kabupaten/kota dan pelaksanaan urusan pemerintahan di daerah kabupaten/kota. Sementara itu, untuk melaksanakan tugas tersebut, Inspektorat Provinsi Nusa Tenggara Barat melaksanakan fungsi perencanaan program pengawasan, perumusan kebijakan dan fasilitasi pengawasan, pemeriksaan, pengusutan, pengujian, dan penilaian tugas pengawasan, pengendalian dan evaluasi pelaksanaan tugas bidang pengawasan, pelaksanaan tugas lainnya yang diberikan oleh Gubernur sesuai dengan tugas dan fungsinya.

Inspektorat Provinsi NTB sebagai lembaga pengawasan pemerintah Daerah dituntut untuk melakukan pengawasan yang obyektif dan akuntabel sehingga dapat menghasilkan pemeriksaan yang dapat dipercaya dan digunakan oleh para pengguna yang berkepentingan. Menurut Standar Umum Pemeriksaan, akuntan memiliki kewajiban menjalankan tugasnya dengan teliti dan cermat serta kemahiran profesionalnya dalam melakukan pemeriksaan. Standar tersebut mengharuskan pemeriksaan dengan rinci dan detail terhadap pekerjaan yang dilakukan entitas dan pengawasan atas pekerjaan oleh auditor lainnya yang membantu tugas pemeriksaan.

Dukungan pengetahuan dan pengalaman yang cukup dapat mendeteksi kecurangan sejak dini terhadap obyek yang ada di Organisasi Perangkat Daerah (OPD) sehingga dapat membuat keputusan berupa rekomendasi secara tepat. Dengan semakin banyaknya pengalaman kerja seorang aparat pengawas intern pemerintah khususnya pengetahuan tentang pendeteksian penyimpangan maka semakin berkembang pula daya piker dan pengetahuan auditor tersebut.

Penelitian ini adalah pengembangan dari penelitian yang telah dilakukan oleh (Batubara, 2009) tentang pengaruh pengalaman untuk mengantisipasi adanya kekeliruan, (Simangunsong, 2008) tentang adanya pengaruh pengalaman dalam mengetahui kekeliruan lewat intuisi, serta (Noviyanti, 2008) tentang skeptisme professional auditor dalam mengetahui kecurangan. (Komala \& Suryani, 2019) menyatakan bahwa faktor pengalaman tidak berpengaruh terhadap skeptisisme 
profesional auditor, sedangkan menurut (Fakhri, 2016) menemukan bahwa faktor pengalaman memiliki pengaruh signifikan terhadap skeptisisme profesional auditor. Penggabungan variabel independen yakni variabel pengetahuan, pengalaman serta perilaku skeptisme professional auditor adalah yang menjadi dasar originalitas dalam penelitian ini.

Dengan objek penelitian yang berbeda, hasil yang diperoleh akan diuji apakah sejalan dengan penelitian sebelumnya. Penelitian ini penting dilakukan untuk menguji ketidakkonsistenan antara hasil penelitian sebelumnya; untuk mengetahui sejauh mana tingkat pengetahuan dan pengalaman yang dimiliki auditor internal dalam mendeteksi kecurangan terhadap ketentuan yang berlaku pada entitas yang diperiksa; serta apakah auditor internal dapat memaksimalkan penggunaan skeptisme professioanal dan intuisi sebagai internal auditor dalam mendeteksi kecurangan pada entitas yang diperiksa.

Kecurangan akibat kesempatan yang dimanfaatkan oleh aparat dalam instansi pemerintah bertentangan dengan tuntutan informasi dan pertanggungjawaban yang akuntabel dari para agent yang telah dipercayakan oleh principal. Pemeriksaan yang dilakukan oleh APIP pada Inspektorat Daerah merupakan salah satu bentuk untuk meminimalisir terjadinya kecurangan dalam instansi pemerintah. Dengan tugas yang diemban oleh APIP ini diperlukan pengembangan potensi kemampuanSumber Daya Manusia melalui pelatihan dan pengembangan.

Dalam melaksanakan tugasnya, APIP dituntut harus memiliki kompetensi sesuai dengan Permenpan No 4 Tahun 2008 yakni auditor diharuskan mempunyai pengalaman, keahlian, pengetahuan, dan keterampilan yang dibutuhkan dalam melaksanakan tugas. (Bonner, 1990) dalam penelitiannya menyimpulkan bahwa pengetahuan mengenai spesifik tugas membantu kinerja pemeriksa (auditor) berpengalaman melalui komponen pemilihan dan pembobotan bukti hanya pada saat penetapan risiko analitis. (Noviyani, 2002) dalam penelitiannya merumuskan bahwa pengalaman berpengaruh positif dan signifikan terhadap pengetahuan auditor tentang jenis kekeliruan. Kesimpulan yang dapat diambil dari penelitian yang dilakukan oleh (Tubbs, 1992) menyatakan bahwa pengalaman seorang auditor berpengaruh pada struktur pengetahuan auditor tentang jenis-jenis kekeliruan yang berbeda yang diketahuinya. (Sucipto, 2007) dalam Eko (2014), menyatakan bahwa pengalaman adalah pengetahuan yang diperoleh dari suatu peristiwa melalui pengamatan langsung maupun berpartisipasi dalam peristiwa tersebut. Berdasarkan hasil penelitian serta kesimpulan dari landasan teori yang ada, maka dapat ditetapkan hipotesis sebagai berikut.

$\mathrm{H}_{1}$ : Semakin tinggi pengetahuan aparat pengawas intern pemerintah maka semakin tinggi kemampuan untuk mendeteksian kecurangan.

Tuntutan informasi yang andal dan dapat dipercaya dari agen (pihak eksekutif) oleh principal (DPRD), menuntut APIP untuk meningkatkan kompetensi yang terdiri dari pengetahuan dan pengalaman yang memadai dengan dukungan skeptisme professional. Sebuah intuisi dilahirkan dari pengalaman seorang auditor. Kurniawan, Pituringsih, \& Alamsyah, (2015) dalam penelitiannya menyimpulkan bahwa pengalaman auditor mampu memberikan dampak positif dan signifikan terhadap kemampuan auditor dalam mendeteksi ketidaktaatan pada SKPD. Auditor yang semakin berpengalaman, maka semakin 
baik pula dalam melakukan tugas pemeriksaannya, selain itu Sukma, (2020) menyatakan pengalaman auditor berpengaruh terhadap pendektesian kecurangan laporan keuangan. Sedangkan terkait dengan kecurangan, auditor yang memiliki pengalaman akan dapat menjalankan prosedur penilaian risiko kecurangan dengan lebih efektif daripada auditor yang kurang berpengalaman (Knap \& Knap, 2001). Dapat disimpulkan bahwa intuisi aparat pengawas internal pemerintah yang didasari dengan pengetahuan dan pengalaman yang memadai, didukung dengan sikap skeptisme profesioanal, akan meningkatkan kemampuan seorang aparat pengawas internal pemerintah dalam mendeteksi terjadinya kecurangan (fraud). Berdasarkan hal tersebut, dapat disusun hipotesis penelitian sebagai berikut.

$\mathrm{H}_{2}$ : Semakin tinggi pengalaman aparat pengawas intern pemerintah maka semakin tinggi kemampuan untuk mendeteksian kecurangan.

Adanya asimetri informasi antara principal dan agent akan mengakibatkan terjadinya Adverse selection. Dalam hal ini, principal tidak dapat mengetahui dengan pasti apakah keputusan yang telah diambil oleh agent adalah berdasarkan informasi yang diperoleh menuntut adanya perilaku selain pengalaman dan pengetahuan yakni skeptisme professional dalam proses pemeriksaan yang dilaksankan oleh seorang auditor. Definisi skeptisisme profesional auditor menurut Shaub \& Lawrence, (1996) adalah Skeptisme profesional adalah pilihan untuk memenuhi tugas auditor profesional untuk mencegah atau mengurangi konsekuensi berbahaya dari perilaku orang lain, yang secara khusus berarti suatu sikap kritis terhadap fakta audit dalam bentuk pertanyaan, keraguan, atau ketidaksetujuan dengan pernyataan klien atau kesimpulan yang dapat diterima umum.

Pada saat mengajukan pertanyaan dan menjalankan prosedur audit, auditor harus menjalankan sikap skeptisme professional dengan tidak cepat puas atas bukti audit yang kurang persuasif dan hanya berdasarkan pada keyakinan bahwa manajemen dan pihak-pihak yang terkait telah bersikapjujur dan memiliki integritas (IFAC, 2004, ISA 240.23-25). Pernyataan dalam ISA No. 200, bahwa dalam sikap skeptisme professional, maka auditor harus membuat penaksiran yang kritis (critical assessment), dengan berpikir untuk selalu mempertanyakan (questioning mind) terhadap kepastian untuk memperoleh bukti audit, cermat terhadap bukti audit yang bersifat kontradiksi terkait dengan dokumen dan reliabilitas, dan memberikan tanggapan terhadap pertanyaan-pertanyaan dan informasi lain yang diperoleh dan manajemen dan pihak yang terkait (IFAC, 2004).

Adnyani et al., (2014) telah menjelaskan bahwa dalam mendeteksi kecurangan dan kekeliruan laporan keuangan, skeptisme professional berpengaruh secara signifikan terhadap tanggungjawab auditor. Kurniawan et al., (2015) menyatakan skeptisme professional berpengaruh terhadap kemampuan auditor itu sendiri dalam mendeteksi terjadinya ketidaktaatan yang dilakukan oleh SKPD, selain itu Permana \& Eftarina, (2020) menyatakan Skeptisisme Profesional berpengaruh positif terhadap kemampuan auditor dalam mendeteksi kecurangan dan Sanjaya, (2017) menyatakan skeptisme professional berpengaruh terhadap kemampuan auditor dalam mendeteksi kecurangan. Atas dasar teori dan penelitian terdahulu diatas, dapat diambil kesimpulan bahwa seorang auditor 
yang memiliki sikap skeptisme professional yang tinggi, akan memiliki kehatihatian dalam menilai bukti dan keterangan dari pihak manajemen yang pada akhirnya dapat membantu dalam proses pengambilan keputusan pada saat dilakukan pemeriksaan. Atas dasar hal tersebut, dapat dirumuskan hipotesis penelitian sebagai berikut:

$\mathrm{H}_{3}$ : Semakin tinggi skeptisme professional aparat pengawas intern pemerintah maka semakin tinggi kemampuan untuk mendeteksian kecurangan.

Tuntutan informasi yang andal dan dapat dipercaya dari agent (pihak eksekutif) dan principal (DPRD), menuntut APIP untuk meningkatkan kompetensi yang terdiri dari pengetahuan dan pengalaman yang memadai dengan dukungan skeptisme professional. Intuisi dilahirkan dari seorang auditor yang telah berpengalaman. Hasil penelitian Agor (1989) menjelaskan bahwa pengalaman membentuk kemampuan belajar dan hal inilah yang kemudian disebut sebagai intuisi, sehingga bukan sekedar berasal dari daya kognitif yang membentuk kemampuan sehingga dapat digunakan sekehendaknya. Disisi lain, (Simangunsong, (2008) dalam risetnya merumuskan adanya pengaruh antara pengalaman dengan intuisi positif yakni semakin tinggi pengalaman pada saat melakukan audit maka semakin baik intuisi yang dimiliki auditor, kemudian Syahputera, (2019) menyatakan intuisi berpengaruh langsung terhadap pendeteksian kekeliruan. Dalam mendeteksi kekeliruan, intuisi berperan sangat penting, disamping itu Simangunsong juga merumuskan bahwa intuisi lebih merupakan variabel independen, bukan partial interverning variabel.

Dalam membantu memecahkan masalah, intuisi berperan penting dengan adanya kerjasama yang erat antara alam bawah sadar yang berpikiran rasional dengan alam bawah sadar yang bersifat intuitif. Intuisi tidak dapat dianggap remeh karena memiliki peranan penting dalam pendeteksian kecurangan. Dalam pengambilan keputusan, peranan intuisi seringkali dimanfaatkan dan dijadikan sebagai alat bantu dalam menyelesaikan masalah yang tidak kalah dengan cara berpikir rasional.

Dapat disimpulkan bahwa seorang auditor yang memiliki pengetahuan dan pengalaman, mampu menggunakan intuisi yang dimiliki secara maksimal dalam menyelesaikan permasalahan yang dihadapi pada saat melakukan pemeriksaan. Atas dasar hal tersebut, dapat dirumuskan hipotesis penelitian sebagai berikut:

$\mathrm{H}_{4}$ : Semakin tinggi intuisi aparat pengawas intern pemerintah maka semakin tinggi kamampuan untuk mendeteksian kecurangan.

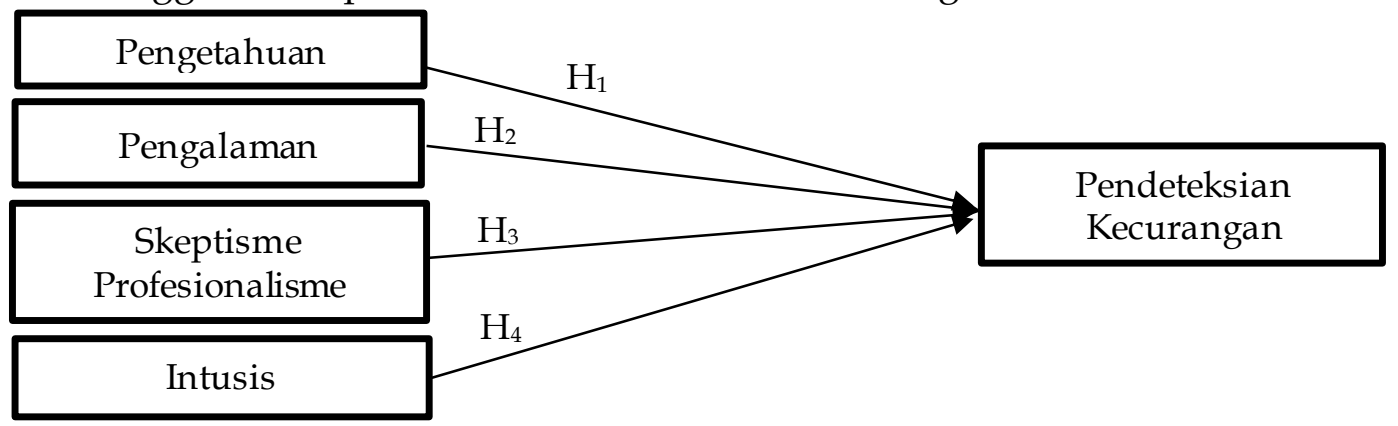

Sumber: Data Penelitian, 2021

Gambar 1. Model Penelitian 
Sesuai dengan landasan teori dan hasil penelitian sebelumnya yang telah dijelaskan diatas, peneliti mengelompokkan 4 (empat) variabel independen, yakni Pengetahuan, Pengalaman, Skeptisme Profesionalisme dan Intuisi yang diduga berpengaruh terhadap Pendeteksian Kecurangan sebagai variabel dependen. Gambar 1 adalah model penelitian yang digunakan.

\section{METODE PENELITIAN}

Penelitian ini menggunakan jenis penelitian asosiatif. Penelitian dilaksanakan pada Inspektorat Provinsi Nusa Tenggara Barat dalam kurun waktu tahun 2021. Pemilihan Inspektorat Provinsi Nusa Tenggara Barat sebagai obyek penelitian ini dikarenakan lokasi tempat APIP menjalankan tugas dan fungsinya sebagai auditor internal pemerintah. Populasi dalam penelitian ini adalah seluruh auditor pemerintah yang berada pada Kantor Inspektorat Provinsi Nusa Tenggara Barat. Sampel penelitian ini ditentukan menggunakan teknisi sensus sehingga seluruh populasi adalah sampel penelitian. Berdasarkan teknik pengambilan sampel tersebut, maka dalam penelitian ini menggunakan sampel sebanyak populasi yang ada yakni sebanyak 49 orang auditor yang bekerja pada Inspektorat Provinsi Nusa Tenggara Barat.

Berikutnya adalah variabel yang digunakan dalam penelitian ini diambil dari beberapa sumber referensi disajikan pada tabel berikut. Selanjutnya dideskripsikan pada paragraf berikut.

Tabel 1. Variabel Penelitian

\begin{tabular}{llc}
\hline No & Variabel & Ditelitioleh \\
\hline 1 & Pendeteksian Kecurangan & Mui (2010) \\
& & Sucipto (2007) \\
& & Koroy (2008) \\
2 & Pengetahuan Auditor & Adnyani etal. (2014) \\
3 & Pengalaman Auditor & Adnyani etal. (2014) \\
4 & Skeptisme Auditor & Anggriawan (2014) \\
5 & Intuisi Auditor & Klein (2002) \\
& & Simangunsong (2008) \\
\hline
\end{tabular}

Sumber: Data Penelitian, 2021

Penjelasan pada Tabel 1 dipaparkan sebagaimana berikut bahwa pendeteksian kecurangan merupakan aktivitas tidak terstruktur yang dilakukan auditor untuk mendapatkan informasi tambahan dari berbagai sumber (Mui, 2010). Auditor yang dapat menjelaskan ketidakwajaran dari laporan keuangan perusahaan dengan proses identifikasi dan membuktikan kecurangan yang ada adalah kemampuan dan kualitas yang ditunjukkan oleh seorang auditor (Sucipto, 2007). Keterampilan teknis, kemampuan bekerja didalam sebuah tim dan kemampuan menasehati adalah beberapa kemampuan yang harus dimiliki auditor agar dapat mendukung auditor dalam melakukan pendeteksian kecurangan. Tidaklah mudah bagi seorang auditor dalam melakukan pendeteksian kecurangan (Koroy, 2008)

Pengetahuan auditor dimaknai sebagai jenjang pendidikan dan pelatihan baik yang bersifat formal maupun nonformal yang melekat pada seorang auditor yang mempengaruhi keterampilannya dalam melaksanakan audit (Adnyani et al., 2014). Indikator yang digunakan untuk mengukur pengetahuan aparat pengawas 
internal pemerintah berdasarkan indikator yang digunakan dalam penelitian (Adnyani et al., 2014) yaitu Pendidikan formal yang dimiliki, diklat auditor yang dimiliki, pelatihan teknis audit yang diikuti, seminar/lokakarya/studi banding, pengetahuan tentang obrik dan standar pemeriksaan.

Pengalaman auditor diartikan sebagai berapa lama waktu yang dibutuhkan oleh auditor melakukan pekerjaannya sesuai dengan bidang dan kompleksitas pekerjaan yang telah dilaksanakan (Adnyani et al., 2014). Indikator yang digunakan untuk mengukur pengalaman aparat pengawas internal pemerintah adalah indikator yang telah digunakan dalam penelitian Adnyani et al. (2014) yaitu lama bertugas sebagai auditor, banyaknya melakukan audit, frekuensi melakukan audit sejenis, jenis-jenis audit yang pernah dilakukan, lamanya waktu menyelesaikan audit.

Skeptisme professional didefinisikan sebagai suatu sikap yang mencakup pikiran yang selalu mempertanyakan dan melakukan evaluasi secara kritis terhadap bukti audit (Asosiasi Auditor Internal Pemerintah Indonesia (AAIPI), 2013). Indikator yang digunakan untuk mengukur sikap skeptisme professional aparat pengawas internal pemerintah dalam penelitian ini adalah indikator yang digunakan dalam penelitian Anggriawan (2014) yaitu rasa ingin tahu, kehatihatian mengambil keputusan, interogatif, evaluasi bukti, dan memahami bukti.

Pengertian dari intuisi auditor adalah alat untuk memaknai pengalaman dan pengetahuan ke dalam sebuah tindakan (Klein, 2002). Indikator yang digunakan untuk mengukur intuisi auditor aparat pengawas internal pemerintah dalam penelitian ini adalah indikator yang telah digunakan sebelumnya oleh (Simangunsong, 2008) yaitu pengetahuan tentang latar belakang, pengetahuan sistem pengelolaan keuangan daerah, pengetahuan tentang audit, pengembangan prosedur audit berdasar pengalaman.

Adapun metode kajian yang dipakai mencakup analisis deskriptif, uji validitas, uji reliabilitas, uji asumsi klasik, dan uji hipotesis (Ghozali, 2011). Pengujian hipotesis dilakukan menggunakan analisis regresi linear berganda. Berikut adalah persamaan regresi yang digunakan dalam penelitian ini.

$Y=a+b_{1} X_{1}+b_{2} X_{2}+b_{3} X_{3}+b_{4} X_{4}+\varepsilon$

Keterangan:

$\mathrm{Y} \quad=$ Pendeteksian kecurangan

a $\quad=$ Konstanta

$\mathrm{b} \quad=$ Koefisien regresi

$\mathrm{X}_{1} \quad=$ Pengetahuan

$\mathrm{X}_{2} \quad=$ Pengalaman

$\mathrm{X}_{3} \quad=$ Skeptisme Professional

$\mathrm{X}_{4} \quad=$ Intuisi

$\varepsilon=$ Standar Error pada tingkat $5 \%$

\section{HASIL DAN PEMBAHASAN}

Berdasar kuesioner yang disebarkan pada Kantor Inspektorat Provinsi Nusa Tenggara Barat berjumlah 49 dengan tingkat pengembalian sebanyak 49 atau $100 \%$, dapat dilakukan uji kualitas data berupa statistik deskriptif dan hasil Regresi Linear Berganda. Untuk karakterisitik responden dapat dilihat pada tabel berikut. 
Tabel 2. Karakteristik Responden

\begin{tabular}{llll}
\hline No & Jenis Kelamin & Frekuensi & Persentase $(\%)$ \\
\hline 1 & Laki-laki & 27 & 55,10 \\
2 & Perempuan & 22 & 44,90 \\
& Jumlah & 49 & 100 \\
\hline
\end{tabular}

Sumber: Data Penelitian, 2021

Berdasarkan Tabel 2, menunjukkan bahwa responden yang paling banyak bekerja pada Kantor Inspektorat Provinsi Nusa Tenggara Barat adalah yang berjenis kelamin laki-laki sebanyak 27 dengan jumlah 27 responden $(55,10 \%)$ sedangkan yang berjenis kelamin perempuan sebanyak 22 responden $(44,90 \%)$.

Tabel 3. Statistik Deskriptif

\begin{tabular}{lccccc}
\hline & $N$ & Min & Max & Mean & Std. Deviation \\
\hline Pengetahuan & 49 & 38 & 50 & 43,22 & 3,105 \\
Pengalaman & 49 & 35 & 45 & 38,22 & 2,284 \\
Skeptisme profesionalisme & 49 & 42 & 57 & 49,77 & 2,374 \\
Intuisi & 49 & 46 & 53 & 49,02 & 1,713 \\
PendeteksianKecurangan & 49 & 49 & 57 & 52,79 & 1,836 \\
\hline
\end{tabular}

Sumber: Data Penelitian, 2021

Berdasarkan Tabel3, maka dapat disimpulkan bahwa total skor tertinggi terdapat pada variabel skeptisme professional dan pendeteksian kecurangan yakni sebesar 57,00 sementara itu total skor terendah terdapat pada variabel pengalaman sebesar 35,00. Skor rata-rata (mean) tertinggi dari data terdapat pada variabel pendeteksian kecurangan yakni sebesar 52,79 sedangkan nilai standar deviasi tertinggi yaitu pengetahuan yakni sebesar 3,015. Sementara itu skor rata-rata terendah standar deviasi terdapat pada variabel intuisi sebesar 1,713. Deskripsi tersebutmenunjukkan bahwa data pada variabel intuisi adalah lebih baik daripada variabel-variabel lainnya karena memiliki standar deviasi yang lebih kecil, sedangkan pada variabel pengetahuan menunjukkan nilai standar deviasi paling besar yang berarti memiliki jawaban yang lebih bervariasi.

Tabel 4. Hasil Regresi Linear Berganda

\begin{tabular}{|c|c|c|c|c|c|}
\hline \multirow[t]{2}{*}{ Variabel } & \multicolumn{2}{|c|}{$\begin{array}{l}\text { Unstandardized } \\
\text { Coefficient }\end{array}$} & \multirow{2}{*}{$\mathrm{T}$} & \multirow{2}{*}{ Sig. } & \multirow[t]{2}{*}{ Keterangan } \\
\hline & B & $\begin{array}{l}\text { Std. } \\
\text { Error }\end{array}$ & & & \\
\hline (Constan) & 59,335 & 7,185 & 8,259 & 0,000 & \\
\hline Pengetahuan & $-0,231$ & 0,115 & $-2,001$ & 0,052 & Ditolak \\
\hline Pengalaman & 0,479 & 0,153 & 3,139 & 0,003 & Diterima \\
\hline Skeptisme profesionalisme & 0,236 & 0,115 & 2,047 & 0,047 & Diterima \\
\hline Intuisi & $-0,544$ & 0,154 & $-3,527$ & 0,001 & Ditolak \\
\hline Uji F & & & 0,003 & & \\
\hline Adjusted R 2 & & & 0,24 & & \\
\hline $\mathrm{N}$ & & & 49 & & \\
\hline
\end{tabular}

Sumber: Data Penelitian, 2021

Berdasarkan Tabel 4, menunjukkan bahwa nilai sig untuk hasil uji kelayakan sebesar 0,003 lebih kecil dari 0,05 artinya variabel pengetahuan, pengalaman, skeptisme professional dan intuisi mampu memperediksi variabel dependen pendeteksian kecurangan. Sementara nilai adjusted $R^{2}$ besarnya angka koefisien determinasi adalah 0,24 sama dengan $24 \%$. Makna dari angka tersebut 
adalah bahwa pengetahuan, pengalaman, skeptisme profesionalisme dan intuisi berpengaruh terhadap pendeteksian kecurangan sebesar $24 \%$ dan sisanya dipengaruhi oleh variabel lain.

Hipotesis pertama pengetahuan mempunyai pengaruh positif terhadap pendeteksian kecurangan. Dari penjelasan diatas berarti bahwa koefisien variabel pengetahuan memiliki tingkat signifikan sebesar 0,052 dimana lebih besar dari alpha 0,05, sehingga hipotesis yang diajukan dapat ditolak. Hal ini menunjukkan semakin tinggi pengetahuan seorang auditor, maka semakin rendah pendeteksian kecurangan. Kecurangan akibat kesempatan yang dimanfaatkan oleh aparat dalam instansi pemerintah bertentangan dengan tuntutan informasi dan pertanggungjawaban yang akuntabel dari para agent yang telah dipercayakan oleh principal. Pemeriksaan yang dilakukan oleh APIP pada Inspektorat Daerah merupakan salah satu bentuk untuk meminimalisir terjadinya kecurangan dalam instansi pemerintah. Sesuai dengan Permenpan No 4 Tahun 2008, APIP dituntut untuk memiliki kompetensi yakni auditor harus mempunyai keahlian, pengetahuan, keterampilan dan pengalaman yang diperlukan dalam melaksanakan tugas. Namun pengetahuan yang tinggi tidak menutup kemungkinan rendahnya pendeteksian kecurangan. Hubungan antara aparat pengawas intern pemerintah dengan aparat pemerintah dapat mengurangi integritas auditor itu sendiri.

Hipotesis kedua pengalaman audit berperan positif mempengaruhi pendeteksian kecurangan. Dari penjelasan diatas diketahui bahwa koefisien variabel pengalaman auditor memiliki pengaruh positif dengan tingkat signifikan sebesar 0,003 yang mana nilai tersebut lebih kecil dari alpha 0,05. Dengan demikian hipotesis yang diajukan dapat diterima yaitu pengalaman mempunyai pengaruh positif terhadap pendeteksian kecurangan, sehingga hal ini menunjukkan semakin banyak pengalaman seorang auditor, maka semakin baik pendeteksian kecurangan dan semakin sedikit pengalaman seorangauditor, maka kurang baik pendeteksian kecurangan. Hasil didukung oleh penelitian yang dilakukan oleh Yustrianti (2001), Hasila dan Dajering (2019), dan Salsabil (2020) yang menyatakan bahwa pengalaman memiliki pengaruh positif pada peningkatan kemampuan mendeteksi kecurangan. Dalam kaitanya dengan teori agensi, pihak manajemen (agen) dan pemilik perusahaan (principal) mempunyai kepentingannya masing-masing. Pihak manajemen pasti akan melakukan berbagai tindakan manipulasi atau kecurangan. Dengan semakin banyaknya pengalaman seorang auditor makan akan semakin dapat menghasilkan berbagai macam dugaan dan menjelaskan temuan audit. Berdasarkan jawaban responden dimensi yang paling dominan dalam membentuk variabel pengalaman adalah dimensi lamanya bekerja, hal ini menunjukkaan semakin berpengalaman seorang auditor serta semakin dia memperdalam dan memperluas kemampuan kerja dan semakin sering seseorang melakukan pekerjaan yang sama maka semakin terampil dan semakin cepat dalam mengambil keputusan. Kemudian disusul dimensi banyaknya tugas audit yang diterima dapat meningkatkan pengalaman dalam pekerjaannya dan peningkatan karirnya.

Hipotesis ketiga skeptisme profesional memiliki pengaruh positif pada pendeteksian kecurangan. Dari penjelasan diatas dapat dijelaskan bahwa koefisien variabel skeptisme profesional mempunyai pengaruh positif dengan 
tingkat signifikan sebesar 0,0047 dimana lebih kecil dari alpha 0,05 sehingga hipotesis yang diajukan dapat diterima yakni skeptisme profesional mempunyai pengaruh positif terhadap pendeteksian kecurangan. Hal ini menunjukkan semakin tinggi skeptisme profesional seorang auditor, maka semakin baik pendeteksian kecurangan dan semakin rendah skeptisme profesional seorang auditor, maka kurang baik pendeteksian kecurangan. Kemampuan auditor pada Inspektorat Provinsi Nusa Tenggara Barat terkait skeptisme professional sudah cukup baik karena mampu memberikan dampak dalam mendeteksi kecurangan sesuai denganStandar Pemeriksaan Keuangan Negara (SPKN). Dalam Pernyataan Standar Pemeriksaan (PSP) 04, dijelaskan bahwa pemeriksaan harus mempertimbangkan risiko terjadinya (fraud) yang secara signifikan dapat mempengaruhi pemeriksaan. Penggunaan skeptisme profesional oleh auditor dalam menilai risiko tersebut bertujuan untuk menentukan faktor dan risiko yang secara signifikan dapat mempengaruhi pekerjaan pemeriksa jika kecurangan sedang terjadi atau mungkin telah terjadi. Sikap auditor yang selalu mencari tahu, mempertanyakan, tidak terburu-buru mengambil keputusan, percaya diri dan keteguhan hati yang kuat maka seorang auditor dapat menjalankan fungsi keprofesionalannya dengan baik. Hasil penelitian ini sejalan dengan penelitian yang dilakukan Noviati (2008) bahwa skeptisme professional berpengaruh dan berperan terhadap pendeteksian kerugian daerah, namun audit yang dilakukan secara berkelanjutan pada audite tertentu dapat menurunkan skeptisme profesional yang dimiliki oleh seorang auditor.

Hipotesis keempat intuisi mempunyai pengaruh positif terhadap pendeteksian kecurangan. Hasil diatas membuktikan bahwa koefisien variabel intuisi memiliki tingkat signifikan sebesar 0,001 dimana lebih kecil dari alpha 0,05, namun memiliki pengaruh negatif. Dengan demikian hipotesis yang diajukan dapat ditolak. Hal ini menegaskan bahwa semakin tinggi intuisi seorang auditor, maka semakin rendah pendeteksian kecurangan. Intuisi merupakan pengetahuan yang diperoleh tanpa pemikiran rasional. Agor (1989) menyatakan bahwa intuisi merujuk pada kemampuan untuk member kode, menyortir, dan mengakses kebermaknaan atau relevansi hasil keputusan masa lalu secara efisien. Dalam penelitiannya Simangunsong (2008) menyimpulkan bahwa pengaruh antara pengalaman dengan intuisi adalah semakin baik intuisi yang dimiliki auditor berpengaruh pada pendeteksian kecurangan. Pada saat penggunaan intuisi dipakai oleh pembuat keputusan, maka pembentukan struktur kognitif akan terbentuk secara otomatis dan secara tidak sadar melalui proses secara otomatis. Intuisi adalah hal yang tidak bisa dianggap remeh dan berperan dalam menyelesaikan masalah sangat besar dan tidak kalah dengan cara berpikir rasional, karenanya intuisi merupakan suatu bentuk dari pengalaman yang dapat dimanfaatkan oleh seseorang sebagai alat bantu untuk pengambilan keputusan. Namun, kenyataanya hasil akhir akan diputuskan ketua tim, hasil penelitian ini menunjukan bahwa intuisi memiliki arah yang berlawanan. Auditor telah bertanggungjawab dan bersikap profesional, hasil pemeriksaaan atau temuan akan tetap diputuskan oleh ketua tim. Hal ini menjadi penyebab pengaruh yang berlawanan intuisi pada Inspektorat Provinsi Nusa Tenggara Barat. Penjelasan tersebut diatas diperkuat definisi oleh (Kyeong, 2003) yang menyatakan bahwa intuisi sebagai kognisi segera suatu konsep tanpa bukti ketat (rigorous proof). 


\section{SIMPULAN}

Tujuan dari penelitian ini adalah untuk menganalisis pengetahuan, pengalaman, skeptisme professional dan intuisi terhadap pendeteksian kecurangan. Berdasarkan hasil penelitian dan pengujian hipotesis yang dilakukan maka dapat diambil beberapa kesimpulan bahwa pengetahuan tidak berpengaruh signifikan terhadap pendeteksian kecurangan. Artinya pengetahuan yang tinggi belum mampu mendeteksi kecurangan. Hipotesis kedua pengalaman berpengaruh positif dan signifikan terhadap pendeteksian kecurangan. Artinya semakin tinggi pengalaman maka semakin baik pendeteksian kecurangan. Hal ini menunjukkan bahwa pengalaman memberikan dampak baik terhadap pendeteksian kecurangan. Skeptisme profesional tidak berpengaruh signifikan terhadap pendeteksian kecurangan. Hal ini menunjukkan semakin tinggi skeptisme profesional seorang auditor, maka semakin baik pendeteksian kecurangan. Sedangkan intuisi berpengaruh negatif signifikan terhadap pendeteksian kecurangan. Peranan intuisi dalam penyelesaian masalah sangat besar dan tidak kalah dengan cara berpikir rasional. Namun, kenyataanya hasil akhir akan diputuskan ketua tim, hasil penelitian ini menunjukan bahwa intuisi memiliki arah yang berlawanan. Auditor telah bertanggungjawab dan bersikap profesional, hasil pemeriksaaan atau temuan akan tetap diputuskan oleh ketua tim.

Keterbatasan dari penelitian ini berdasarkan model penelitian yang digunakan, bahwa tingkat koefisien determinasi mempunyai nilai yang masih rendah sehingga mengindikasikan bahwa selain variabel pengetahuan, pengalaman, skeptisme profesional dan intuisi yang telah dibangun dalam penelitian ini masih ada variabel lain yang mempengaruhi pendeteksian kecurangan. Selain itu, ruang lingkup penelitian ini hanya dilakukan pada Inspektorat Provinsi Nusa Tenggara Barat sehingga generalisasi hasil temuan dan rekomendasi penelitian ini kurang dapat diberlakukan bagi inspektorat, sebaiknya untuk penelitian selanjutnya dapat dilakukan untuk cakupan yang lebih luas dan dengan variabel yang lebih terkini dan menarik. Pengembangan penelitian yang akan datang diharapkan dapat menambahkan dan mengembangkan obyek penelitian, seperti inspektorat daerah, pengembangan instrument penelitian yang lebih baik dengan mengumpulkan referensi terkait penelitian sejenis, sehingga diharapkan dapat diperoleh pemahaman yang lebih baik tentang pendeteksian kecurangan. Disamping itu penelitian selanjutnya diharapkan juga dapat mengembangkan variabel penelitian, tidak hanya pada variabel pengetahuan, pengalaman, skeptisme professional dan intuisi.

\section{REFERENSI}

Adnyani, N., Atmadja, A. T., \& Herawati, N. T. (2014). Pengaruh Skeptisme Profesional Auditor, Independensi, Dan Pengalaman Auditor Terhadap Tanggungjawab Auditor Dalam Mendeteksi Kecurangan Dan Kekeliruan Laporan Keuangan. E-Journal S1 AK Universitas Pendidikan Ganesha, 2(1), 111.

Ashton, Alison Hubbard. (1991). Experience Effects and Error Frequency Konwledge as Potential Determinants of Audit Exertise, The Accounting Review. 218-239. 
Asosiasi Auditor Internal Pemerintah Indonesia (AAIPI). (2013). Standar Audit Intern Pemerintah Indonesia.

Badan Pemeriksa Keuangan Republik Indoneisa. (2007). Peraturan Badan Pemeriksa Keuangan tentang Standar Pemeriksaan Keuangan Negara No 1 Tahun 2007.

Bali.bisnis.com. (2021). Bappenas: Sirkuit Mandalika Tingkatkan Devisa dan Pendapatan Daerah. Bali.Bisnis. Com.

Batubara, K. (2009). Pengaruh Pengalaman dan Pengetahuan Aparat Pengawas Intern Pemerintah Terhadap Pendeteksian Penyimpangan Dengan Intuisi Sebagai Variabel Intervening di Inspektorat Kabupaten Deli Serdang.

Baylor, A, L. (1997). A Three-Component Conception of Intuition: Immediacy, Sensing Relationships, and Reason. New Ideas in Psychology, 15(2), 185-194.

Bonner, S. (1990). Experience Auditing: The Effects Role in of Knowledge TaskSpecific Knowledge. American Accounting Association, 65(1), 72-92.

Choo, F., \& Trotman, K. T. (1991). The relationship between knowledge structure and judgments for experienced and inexperienced auditors. Accounting Review, Vol. 66, 464-485. https://www.jstor.org/stable/247805.

Eisenhardt, K. (1989). Teori Portofolio dan Analisis Investasi (Edisi ke 10). Academy of Management Review, 14(1), 57-74. http://www.jstor.org/stable/258191.

Fakhri, E. A. (2016). Pengaruh Pengalaman, Pendidikan dan Pelatihan, dan Situasi Audit terhadap Skeptisisme Profesional Auditor. Universitas Brawijaya, Malang.

Falah, S. (2006). Pengaruh Budaya Etis Organisasi Dan Orientasi Etika Terhadap Sensitivitas Etika (Studi Empiris Tentang Pemeriksaan Internal di Bawasda Pemda Papua) [Universitas Diponegoro]. https:/ / core.ac.uk/download/pdf/11717518.pdf

Ghozali, I. (2011). Aplikasi Analisis Multivariate Dengan Program SPSS. Semarang: Badan Penerbit Universitas Diponegoro.

Hall, J. A., \& Singleton, T. (2007). Audit Teknologi Informasi dan Assurance (Edisi Kedu). Salemba Empat.

Harhinto, T. (2004). Pengaruh keahlian dan independensi terhadap kualitas audit studi empiris pada KAP di Jawa Timur. Universitas Diponegoro.

Herliansyah, Y., \& Ilyas, M. (2006). Pengaruh Pengalaman Auditor Terhadap Penggunaan Bukti Tidak Relevan dalam Auditorium Judgment. SNA 9 Padang, 23-26.

Indriantoro, N., \& Supomo, B. (1999). Metodologi Penelitian Bisnis untuk Akuntansi dan Manajemen (Edisi Pert). BPFE.

International Auditing and Assurance Standards Boards (IAASB). (2004). International Standard on Auditing. New York: IFAC.

Jensen, M. C., \& Meckling, W. H. (1976). The Theory of The Firm: Managerial Behaviour, Agency Cost, and Ownership Structure. Journal of Financial and Economics, 3(4), 305-360.

Klein, A. (2002). New York University School Of Law Nyu Center for Law and Economics Earnings Management. Journal of Accounting and Economics, 33(06), 375-400. http:/ / www.sciencedirect.com/science/article/pii/S0165410102000599

Komala, A., \& Suryani, E. (2019). Pengaruh Independensi, Kompetensi Dan Pengalaman Auditor Terhadap Skeptisisme Profesional Auditor (Survei 
Pada Auditor Kantor Akuntan Publik Di Wilayah Bandung). E-Proceeding of Management, 6(2), 3225-3232.

Kopp, L., Lemon, W. M., \& Rennie, M. (2003). A Model of Trust and Professional

Skepticism in the Auditor-Client Relationship. Presentastion, School of Accountancy Seminar Series, 29(1), 279-293. http:/ / citeseerx.ist.psu.edu/viewdoc/ download?doi=10.1.1.515.8784\&re $\mathrm{p}=$ rep1\&type $=$ pdf.

Koroy, R. T. (2008). Pendeteksian Kecurangan (Fraud) Laporan Keuangan oleh Auditor Eksternal. Jurnal Akuntansi Dan Keuangan, 10(1), 23-33. https:/ / doi.org/10.37751/parameter.v2i1.8

Kurniawan, A., Pituringsih, E., \& Alamsyah, D. (2015). KETIDAKTAATAN (Studi Empiris pada Inspektorat Provinsi NTB dan Kabupaten/Kota se-Pulau Lombok). $11-21$.

Kusuma, N. F. B. A. (2012). Pengaruh Professionalisme Auditor, Etika Profesi dan Pengalaman Auditor terhadap Pertimbangan Tingkat Materialitas. Universitas Negeri Yogyakarta.

Kyeong Ha, R. (2003). Problem-based instruction in mathematics. RIC Clearinghouse for Science Mathematics and Environmental Education.

Mardiasmo. (2005). Akuntansi Sektor Publik. Yogyakarta. Penerbit Andi.

Menteri Negara Pendayagunaan Aparatur Negara Republik Indonesia. (2008). Peraturan Menteri Negara Pendayagunaan Aparatur Negara Nomor: PER/05/M.PAN/03/2008.

Mui, G. Y. (2010). Factors That Impact On Internal Auditors' Fraud Detection Capabilities - A Report For The Institute of Internal Auditors Australia. Center for Business Forensics HELP University Malaysia.

Noviyani, P. dan B. (2002). Pengaruh Pengalaman dan Pelatihan Terhadap Struktur Pengetahuan Auditor Tentang Kekeliruan. Makalah Simposium Nasional Akuntansi, 5, 1-25.

Noviyanti, S. (2008). Skeptisme Profesional Auditor dalam Mendeteksi Kecurangan. Jurnal Akuntansi Dan Keuangan Indonesia, 5(1), 102-125.

Pemerintah Provinsi Nusa Tenggara Barat. (2008). Peraturan Daerah Provinsi Nusa Tenggara Barat Nomor 8 Tahun 2008 Tentang Organisasi Dan Tata Kerja Inspektorat, Bappeda Dan Lembaga Teknis Daerah Provinsi Nusa Tenggara Barat.

Permana, Y., \& Eftarina, M. (2020). Peran Whistleblowing System dalam Memoderasi Pengaruh Skeptisme Profesional Terhadap Kemampuan Auditor dalam Mendeteksi Kecurangan. Prosiding Seminar Nasional Pakar Ke 3 Tahun 2020 Buku 2: Sosial Dan Humaniora, 3(2), 2.14.1-1.14.6.

Sanjaya, A. (2017). Pengaruh Skeptisisme Profesional, Independensi, Kompetensi, Pelatihan Auditor, Dan Resiko Audit Terhadap Tanggung Jawab Auditor Dalam Mendeteksi Kecurangan. Jurnal AKuntansi Bisnis, 53(9), 1689-1699. https:/ / doi.org/10.1017/CBO9781107415324.004

Scott, William, R. (1997). Financial Accounting Theory, International Edition, New Jersey: Prentice-Hall, Inc.

Shaub, M. K., \& Lawrence, J. E. (1996). Ethics, Experience and Professional Skepticism: A Situational Analysis. Behavioral Research in Accounting., 8.1996, 124-157. 
Simangunsong, S. (2008). Pengaruh Pengalaman terhadap Kemampuan Mendeteksi Kekeliruan dengan Intuisi sebagai Variabel Intervening (Studi Empiris pada Perwakilan BPK-RI di Medan.

SuaraNTB.com. (2019). BPK Telisik Indikasi Kebocoran Retribusi Sektor Pariwisata di NTB. Www.Suarantb.Com. https://www.suarantb.com/bpk-telisikindikasi-kebocoran-retribusi-sektor-pariwisata-di-ntb/

Sucipto, A. (2007). Analisis pengaruh pengetahuan dan pengalaman terhadap kemampuan akuntan pemeriksa dalam mendeteksi kekeliruan padakantor akuntan publik di Surabaya. Bachelor thesis, Petra Christian University

Sugiyono. (2014). Metode Penelitian KuantitatifKualitatifdan RED. Jakarta. Alfabeta.

Sukma, E. (2020). Pengaruh Pengalaman Auditor, Independensi, dan Keahlian Profesional Terhadap Kemampuan Auditor Mendeteksi Kecurangan Laporan Keuangan dengan Skeptisme Profesional sebagai Variabel Moderasi. 1-6.

Sularso, Sri dan Na'im, A. (1999). Analisis Pengaruh Pengalaman Akuntan pada Pengetahuan dan Penggunaan Intuisi dalam Mendeteksi Kekeliruan. Jurnal Riset Akuntansi Indonesia, 2(1), 72-94.

Suprajadi, L. (2009). Teori Kecurangan, Fraud Awareness, dan Metodologi Untuk Mendeteksi Kecurangan Pelaporan Keuangan. Bina Ekonomi Majalah Ilmiah Fakultas Ekonomi Unpar. Bina Ekonomi, 13(2). https:/ / doi.org/10.26593/be.v13i2.722.\%p

Syahputera, R. (2019). Pengaruh Pengalaman Dan Keahlian Terhadap Mendeteksi Kekeliruan Dengan Intuisi Sebagai Variabel Intervening Pada Kantor Akuntan Publik Di Medan. 5(1), 72-94.

The Oxford English Dictionary. (1978). The Oxford English Dictionary Volume III. Oxford University Press. Great Britain.

Tobing, T., Rumapea, M., \& ... (2017). Peranan Auditor Intern Dalam Pencegahan Dan Pendeteksian Kecurangan Pada Pt Permata Indonesia Cabang Medan. Majalah Ilmiah $\quad \ldots, \quad 7, \quad 64-72$. https:/ / ejurnal.methodist.ac.id/index.php/methoda/article/view/316\% 0Ahttps: / / ejurnal.methodist.ac.id/index.php/methoda/article/downloa $\mathrm{d} / 316 / 278$

Tuanakotta, T. M. (2007). Akuntansi Forensik dan Audit Investigatif. Jakarta: Lembaga Penerbit Fakultas Ekonomi Universitas Indonesia (LPFE UI).

Tubbs, R. M. (1992). The Effect of Experience on Auditors Organization and Amount of Konowledge. The Accounting Review, 783-801. 